CASSOWARY Volume 2(2): 176 - 192

ISSN : 2614-8900

E-ISSN : 2622-6545

CProgram Pascasarjana Universitas Papua, https://pasca.unipa.ac.id/

\title{
Pengaruh suhu rendaman dan media tumbuh terhadap daya kecambah benih dan pertumbuhan tanaman Indigofera zollingeriana
}

\author{
The Impact of Water Heat Treatment and Growth Media on Seed Viability and Growth \\ of Indigofera zollingeriana
}

Firna Novita Yafur, Sientje D. Rumetor*, Onesimus Yoku

Program Studi S2 Ilmu Peternakan, Program Pascasarjana Universitas Papua Jalan Gunung Salju, Amban, Manokwari, Kodepos 98314, Papua Barat, Indonesia.

*Email: sientjdr@gmail.com

\begin{abstract}
Indigofera zollingeriana is one of legumes that contains high nutrient contents (crude protein: $29,16 \% \pm 2,37 \%$; fibres: 14,02 $\pm 2,48 \%$; Ca: 1,78-2,48\%; P: 0,34$0,46 \%$ and protein digestibility: $82,3-86,3 \%$ ). The purpose of the study was to identify and analyse the effect of initial water heat treatment and different media on seed viability and plant growth of Indigofera zollingeriana. This study will be an useful basic information on how to cultivate Indigofera zollingeriana as one of forage feed in Papua Barat (West Papua). The result of the study could be used by the farmers. The design of the study was using complete randomize design with two factors: water heat treatment and different media. Water heat treatments consist of two different temperatures: $70 \mathrm{oC}$ and $80 \mathrm{oC}$, and growth media had three different media: $100 \% ; 75 \%$ soil $+25 \%$ compos; $50 \%$ soil $+50 \%$ compos. Every treatment combination had three replicates so in total the study had 18 unit experiments. Time of germination (days), seed viability (\%), plant height (cm/week), number of leaves (per week), leaf length and width (cm/week), stem and leaf ratio, root length $(\mathrm{cm} /$ week), number of root nodules. The results showed that time of germination and seed viability indicated the best result by using water heat treatment at $70^{\circ} \mathrm{C}$. Combination of water heat treatment at $80 \mathrm{oC}$ and $100 \%$ of soil as growth media showed the highest plant growth, the most number and width of leaf of Indigofera zollingerian, while stem and leaf ratio and root length were high with combination of water heat treatment at $80^{\circ} \mathrm{C}$ and media with $50 \%$ soil and compos. The greatest number of nodules were found in the plants with water heat treatment at $80 \mathrm{oC}$ and media with $75 \%$ soil $+25 \%$ compos.
\end{abstract}

Key words: Indigofera zollingeriana, water heat treatment, media, viability, growth.

ABSTRAK: Indigofera zollingeriana adalah salah satu jenis Leguminosa pohon yang memiliki kandungan nutrisi yang tinggi (PK: 29,16\% $\pm 2,37 \%$; SK: 14,02 $\pm 2,48 \%$; Ca: 1,78-2,48\%; P: 0,34-0,46\% dan kecernaan protein: 82,3-86,3\%). Penelitian ini bertujuan untuk mengetahui dan menganalisis pengaruh perlakuan suhu awal rendaman 
di dalam air panas dan penggunaan beberapa media tumbuh terhadap daya kecambah benih dan pertumbuhan tanaman Indigofera zollingeriana. Manfaat dari penelitian ini adalah sebagai informasi awal untuk mengetahui dan menganalisis cara pembudidayaan tanaman Indigofera zollingeriana sebagai salah satu hijauan pakan di Provinsi Papua Barat yang sekaligus dapat dimanfaatkan oleh masyarakat/peternak. Rancangan yang digunakan adalah Rancangan Acak Lengkap (RAL) pola Faktorial, dengan dua faktor, yaitu faktor suhu rendaman (terdiri dari dua level yaitu: $70^{\circ} \mathrm{C}$ dan $80^{\circ} \mathrm{C}$ ) dan faktor media tumbuh (terdiri dari tiga level yaitu: $100 \%$ tanah; $75 \%$ tanah $+25 \%$ top kompos; dan $50 \%$ tanah $+50 \%$ top kompos). Kombinasi perlakuan tersebut diulang sebanyak 3 kali, sehingga diperoleh 18 satuan percobaan. Variabel yang diukur adalah lama berkecambah (hari), daya kecambah (\%), tinggi tanaman ( $\mathrm{cm} / \mathrm{minggu})$, jumlah daun (helai/minggu), panjang daun dan lebar daun ( $\mathrm{cm} / \mathrm{minggu})$, rasio daun dan batang, panjang akar $(\mathrm{cm})$ dan jumlah bintil akar. Pada variabel lama berkecambah dan daya kecambah terbaik dari benih Indigofera zollingeriana, terdapat pada suhu awal rendaman $70^{\circ} \mathrm{C}$ dan media tumbuh $100 \%$ tanah. Variabel tinggi tanaman, jumlah daun dan lebar daun terbaik dari tanaman Indigofera zollingeriana adalah dengan menggunakan suhu awal rendaman $80^{\circ} \mathrm{C}$ dan media tumbuh $100 \%$ tanah, sedangkan pada variabel rasio daun dan batang serta panjang akar, suhu awal rendaman $80^{\circ} \mathrm{C}$ dan media tumbuh $50 \%$ tanah $+50 \%$ top kompos adalah yang terbaik. Pada variabel jumlah bintil akar, suhu awal rendaman dan media tumbuh terbaik adalah $80^{\circ} \mathrm{C}$ dan $75 \%$ tanah $+25 \%$ top kompos.

Kata kunci: Indigofera zollingeriana, suhu rendaman, media tumbuh, daya kecambah, pertumbuhan

\section{PENDAHULUAN}

Keberhasilan suatu usaha peternakan khususnya usaha ternak ruminansia ditentukan oleh tiga faktor yaitu pakan (feeding), bibit (breeding) dan manajemen (management) yang baik. Bibit yang berkualitas baik, akan mampu tumbuh dengan cepat untuk menghasilkan produk yang optimal. Optimalisasi produk juga ditentukan oleh pakan dan manajemen secara terpadu. Pakan merupakan salah satu sarana produksi yang sangat penting dan sangat strategis dalam usaha budidaya ternak ruminansia, bukan saja karena kecukupan dan mutunya yang secara langsung berkorelasi dengan performans ternak, tetapi juga karena biaya pakan merupakan komponen terbesar dalam usaha budidaya ternak ruminansia. Hijauan merupakan pakan basal bagi ternak ruminansia, namun menurut Topps (1992) selain jenis rumput-rumputan yang merupakan hijauan utama bagi ternak ruminansia, potensi jenis leguminosa sangat strategis pada agroekosistem tertentu, terutama di daerah tropis dan sub tropis. McDonald et al. (2002) dalam Tarigan (2009) melaporkan bahwa kandungan protein dan mineral (kalsium dan fosfor) pada jenis-jenis legum lebih tinggi dibandingkan dengan rumput. Salah satu jenis legum yang telah dikembangkan adalah Indigofera $s p$. 
Pada awal tahun 2016 tanaman Indigofera mulai dikembangkan sebagai pakan ruminansia pada Balai Pembibitan Ternak dan Hijauan Makanan Ternak Provinsi Papua Barat, di Satuan Pemukiman V (SP V) Prafi, Manokwari. Spesies Indigofera yang dikembangkan adalah Indigofera zollingeriana dan diperbanyak dengan menggunakan biji. Hal ini sesuai dengan pernyataan Herdiawan dan Krisnan (2014) bahwa Indigofera zollingeriana dapat dibudidayakan secara generatif menggunakan biji dan secara vegetatif dengan menggunakan stek batang tanaman. Selanjutnya Gandhi et al. (2011) menyatakan bahwa tanaman ini lebih mudah dibudidayakan dengan menggunakan biji, dibandingkan bagian tanaman lainnya. Pemanfaatan Indigofera zollingeriana sebagai pakan ternak, karena legum ini memiliki kandungan nutrisi yang tinggi dan palatabel bagi ternak (kisaran nilai PK: $29.16 \pm 2.37 \%$; SK: $14.02 \pm 2.48 \%$; Ca: $1.78-2.48 \%$; P: $0.34-0.46 \%$ dan kecernaan protein: $82.3-86.3 \%$ ), serta mudah dibudidayakan, dapat menghasilkan polong dan benih dengan biji bernas, daya adaptasi tinggi/tahan kekeringan, tersedia sepanjang tahun dengan interval pemanenan setiap 60 hari sekali (Abdullah, 2014). Selain itu, Tarigan (2009) melaporkan bahwa uji coba palatabilitas Indigofera zollingerina hingga taraf $45 \%$ pada kambing kacang, dapat meningkatkan efisiensi pakan dan bobot badan.

Indigofera zollingeriana memiliki benih berwarna coklat dan coklat kehitaman serta bulat berisi dengan viabilitas yang lebih baik jika dibandingkan dengan benih berwarna kuning atau hijau kecoklatan (Abdullah, 2014). Perbanyakan tanaman Indigofera zollingeriana dengan menggunakan biji, tentunya memerlukan perlakuan dan media yang sesuai untuk mempercepat proses perkecambahan dan pertumbuhan tanaman ini. Menurut Hassen et al., (2007) Indigofera spp. memiliki biji dengan kulit luar yang keras, sehingga diperlukan perlakuan sebelum ditanam untuk mempercepat daya kecambah (pemecahan dormansi). Selanjutnya Bajang et al. (2015) melaporkan bahwa salah satu faktor penentu perkecambahan adalah dengan menggunakan media tumbuh yang efektif.

Masa kritis perbanyakan tanaman dengan menggunakan biji adalah pada perlakuan awal. Beberapa penelitian yang dilakukan oleh Herdiawan et al., (2014) mengawali proses penanaman Indigofera zollingeriana dengan proses perendaman biji dalam air panas dengan suhu awal $70^{\circ} \mathrm{C}$ dan $80^{\circ} \mathrm{C}$ selama 2 jam, yang dapat mempercepat proses perkecambahan dari tanaman tersebut. Demikian halnya dengan penelitian yang dilakukan oleh Hassen et al. (2007) dengan menggunakan suhu $93^{\circ} \mathrm{C}$ selama 15 menit pada suhu awal perendaman biji Indigofera zollingeriana dalam air panas untuk mempercepat proses perkecambahan benih. Selanjutnya Suprayitno (1981) melaporkan bahwa biji Lamtoro yang akan dijadikan bibit memiliki kulit biji yang keras, tebal dan berlilin, sehingga tanpa perlakuan peretasan biji maka dapat berkecambah setelah 2 hingga 3 bulan. Ani (2006) menyatakan bahwa peretasan kulit dimaksudkan agar dapat memecahkan kulit biji, sehingga lembaga muda tumbuh terbuka menembus kulit biji yang telah retas, lalu inti lembaga ini tumbuh leluasa menjadi kecambah dengan akar tunggangnya yang langsung mampu menyerap makanan yang tersimpan dalam tanah sedangkan kuncup 
lembaganya tumbuh leluasa menjadi calon pohon yang kuat.

Sumanto dan Sriwahyuni (1993) juga berpendapat bahwa perlakuan benih memberikan kecepatan tumbuh yang paling baik karena air dan oksigen yang dibutuhkan untuk perkecambahan dapat masuk ke benih tanpa halangan sehingga benih dapat berkecambah. Semakin lama biji direndam, maka semakin besar masuknya air ke dalam endosperm biji, sehingga memungkinkan benih berkecambah dengan cepat tetapi ada batasan tertentu untuk lamanya perendaman, karena semakin lama perendaman akan mengakibatkan kerusakan pada benih. Selain faktor suhu perendaman yang digunakan untuk peretasan benih Indigofera zollingeriana, media tumbuh juga penting untuk diperhatikan dalam menunjang perkecambahan dan pertumbuhan tanaman ini. Hardjowigeno (1989) mengemukakan bahwa beberapa media tumbuh yang digunakan untuk penanaman Indigofera $s p$. berupa tanah dan bahan organik seperti kompos. Media tanah yang baik adalah dapat menyediakan air dan unsur hara yang cukup, dengan kemampuan menahan air dan ruang yang cukup untuk pertumbuhan akar. Selain itu, kandungan bahan organik dalam tanah dapat meningkat dengan adanya penggunaan pupuk organik, yang dapat mempengaruhi dan menambah kebaikan fisik, biologi dan kimiawi tanah.

Indigofera zollingeriana adalah tanaman yang memiliki tekstur kulit luar biji yang keras sehingga perlakuan perendaman pada suhu awal air panas yang ditunjang dengan penggunaan media tumbuh yang sesuai perlu diteliti.

Penelitian ini bertujuan untuk mengetahui dan menganalisis pengaruh perlakuan suhu awal rendaman di dalam air panas dan penggunaan beberapa media tumbuh terhadap daya kecambah benih dan pertumbuhan tanaman Indigofera zollingeriana.

\section{MATERI DAN METODE}

Penelitian ini dilakukan di Jl. Brawijaya Kabupaten Manokwari, Laboratorium Tanah Fakultas Pertanian UNIPA Manokwari untuk analisis fisika tanah, dan Seameo Biotrop Services Laboratory-Bogor untuk analisis sifat kimia tanah dan pupuk yang digunakan pada penelitian ini. Penelitian ini berlangsung bulan Agustus- November Tahun 2017.

Pelaksanaan penelitian tanaman Indigofera zollingeriana dibagi dalam 2 (dua) tahap, yaitu tahap pertama untuk mengamati perkecambahan yang dilaksanakan selama 45 hari dan tahap kedua untuk mengamati pertumbuhan yang dilaksanakan selama 45 hari. Rancangan percobaan pada penelitian ini menggunakan rancangan acak lengkap pola faktorial $2 \times 3 \times 3$, dimana suhu awal rendaman dan media tumbuh sebagai faktor perlakuan (faktor pertama adalah suhu rendaman: $\mathrm{S} 1=$ $70^{\circ} \mathrm{C}$ dan $\mathrm{S} 2=80^{\circ} \mathrm{C}$ dan faktor kedua adalah: $\mathrm{M} 1=100 \%$ tanah; $\mathrm{M} 2=75 \%$ tanah $+25 \%$ top kompos dan M3 = $50 \%$ tanah $+50 \%$ top kompos.

Sebelum penelitian dilaksanakan, dilakukan berbagai persiapan yaitu pembuatan rumah sungkup berukuran $2 \mathrm{~m} \times 3 \mathrm{~m}$; persiapan media tumbuh berupa tanah, campuran tanah dan top kompos dengan perbandingan sesuai perlakuan; persiapan biji Indigofera zollingeriana yang diseleksi berdasarkan bentuk morfologisnya. Biji normal dicirikan dengan telah berwarna coklat kehitaman, terdapat relief pada setiap segmen benih (menunjukkan benih bernas), dan bentuk utuh tanpa kerusakan fisik (Abdullah dan Kumalasari, 2016); serta persiapan 
materi penelitian (bahan dan alat) yang digunakan.

Pelaksanaan penelitian adalah sebagai berikut:

Tahap pertama.

Persiapan sampel untuk analisis Laboratorium:

- Sampel tanah ditimbang sebanyak 1 $\mathrm{kg}$ (tanpa pengayakan) dan dimasukkan ke dalam plastik, guna proses analisis fisika yang dilakukan di Laboratorium Tanah, Fakultas Pertanian Universitas Papua.

- Sampel tanah dan top kompos yang telah diayak, ditimbang masingmasing sebanyak $2 \mathrm{~kg}$ serta dimasukkan ke dalam plastik dan dikirim ke Seameo Biotrop Services Laboratory-Bogor untuk analisis kimia.

a. Pemilihan benih dan penanaman :

- Pada masing-masing media perlakuan menggunakan 25 benih Indigofera zollingeriana, sehingga kebutuhan benih untuk 18 satuan percobaan adalah sebanyak 450 benih.

- Media tumbuh dimasukkan ke dalam nampan, diletakkan sesuai dengan kombinasi perlakuan yang telah diacak.

- Biji Indigofera zollingeriana terlebih dahulu direndam dalam air biasa selama 5 menit, dan biji yang terapung tidak digunakan dalam penelitian ini.

- Benih selanjutnya direndam dalam air panas dengan suhu awal rendaman $70^{\circ} \mathrm{C}$ dan $80^{\circ} \mathrm{C}$ selama 2 jam. Setelah 2 jam, benih tersebut ditiriskan.

- Media tumbuh dibasahi dengan air secukupnya dan benih Indigofera zollingeriana dapat ditanam dengan cara dibuat lubang dengan kedalaman $\pm 1 \mathrm{~cm}$ dan jarak tanam $\pm 5 \mathrm{~cm}$.
- Penyiraman dengan air bersih dilakukan $2 x$ dalam sehari (pagi dan sore), jika kondisi media tumbuh masih basah maka penyiraman hanya dilakukan 1 kali sehari. Selain itu, jika terdapat gulma, maka dilakukan pembersihan.

- Pengamatan untuk mengetahui daya kecambah dari benih Indigofera zollingeriana, dilakukan setiap hari selama 45 hari.

\section{Tahap kedua.}

Pada tahap kedua kegiatan yang dilakukan, adalah sebagai berikut:

a. Benih yang telah berkecambah dan tumbuh normal menjadi tanaman dengan daun sempurna pada penelitian tahap pertama, selanjutnya dipindahkan ke polibag dengan ukuran $25 \mathrm{~cm}$ x $25 \mathrm{~cm}$ dengan media tumbuh yang sama, yaitu tanah serta campuran tanah dan top kompos dengan perbandingan yang berbeda.

b. Polibag diletakkan $15 \mathrm{~cm}$ menurut baris dan $15 \mathrm{~cm}$ menurut kolom yang akan mempermudah untuk melakukan pengamatan dan pengukuran.

c. Pengamatan dan pengukuran dilakukan setiap minggu selama 45 hari untuk mengetahui pertumbuhan tanaman Indigofera zollingeriana.

Data yang diperoleh dalam penelitian ini, dianalisis menggunakan Multivariate Analysis of Variance (Manova) dalam rancangan acak lengkap (RAL) pola faktorial pada tahap pertama dan kedua. Pengolahan data menggunakan Program Excel dan SPSS versi 24. Perlakuan yang menunjukkan pengaruh signifikan, dilanjutkan dengan Uji Lanjut Tukey Honestly Significant Difference (HSD) (Steel and Torrie, 1995). Model linier analisis keragaman pada penelitian ini adalah (Steel dan Torrie, 1995): 


$$
\mathrm{Y}_{\mathrm{ijk}}=\mu+\mathrm{S}_{\mathrm{i}}+\mathrm{M}_{\mathrm{j}}+(\mathrm{SM})_{\mathrm{ij}}+\varepsilon_{\mathrm{ijk}}
$$

Keterangan :

$\mathrm{Y}_{\mathrm{ijk}}$ : pengamatan terhadap daya kecambah dan pertumbuhan ke-k yang memperoleh kombinasi perlakuan suhu rendaman ke-i dari faktor $\mathrm{S}$ dan media tumbuh ke-j dari faktor M

$\mu \quad$ : rata-rata umum

$\mathrm{S}_{\mathrm{i}} \quad$ : pengaruh suhu rendaman ke-i (i=1 dan 2)

$\mathrm{M}_{\mathrm{j}} \quad$ : pengaruh media tumbuh ke-j $(\mathrm{j}$ $=1,2$ dan 3 )

$(\mathrm{SM})_{\mathrm{ij}}$ : pengaruh interaksi suhu rendaman ke-i dan media tumbuh ke-j $\quad(i=1,2$ dan $\mathrm{j}=1,2,3)$

$\varepsilon_{\mathrm{ijk}} \quad$ : galat percobaan

\section{HASIL DAN PEMBAHASAN}

\section{Karakteristik Tanah dan Top Kompos serta Suhu dan Kelembaban Rumah Sungkup}

Tanah yang digunakan dalam penelitian ini bertekstur lempung berliat, berwarna coklat tua yang didominasi dengan fraksi pasir $(44,6 \%)$ dan memiliki $\mathrm{pH}$ 5,9. Selain itu, memiliki $\mathrm{C}$ organik, rasio $\mathrm{C} / \mathrm{N}$ dan Kapasitas Tukar Kation (KTK) dengan kriteria rendah, namun memiliki kriteria sedang pada parameter $\mathrm{N}$ total, serta kriteria tinggi dan sangat tinggi, masing-masing pada parameter $\mathrm{P}_{2} \mathrm{O}_{5}$ tersedia dan $\mathrm{P}_{2} \mathrm{O}_{5}$ potensial (Lampiran 11). Hardjowigeno (2010) menyatakan bahwa pentingnya $\mathrm{pH}$ tanah pada penyerapan unsur-unsur hara tanaman, karena tanah dengan $\mathrm{pH}$ netral akan lebih mudah menyerap unsur-unsur hara, karena mudah larut dalam air. Sedangkan pada tanah yang masam, banyak ditemukan unsur-unsur mikro yang mudah larut yang merupakan racun bagi tanaman. Namun dengan $\mathrm{pH}$ tanah 5,5 atau lebih, dapat mengakibatkan bakteri tanah (bakteri pengikat nitrogen) berkembang dengan baik. Selanjutnya dikatakan pula bahwa kapasitas tukar kation (KTK) merupakan sifat kimia tanah yang berhubungan dengan kesuburan tanah, sehingga dengan nilai KTK yang tinggi, maka tanah dapat menyediakan unsur hara lebih baik jika dibandingkan dengan nilai KTK yang rendah. Ginting et al., (2012) menyatakan bahwa tanaman Indigofera $s p$. dapat tumbuh dan berkembang di tanah liat atau lempung berliat dengan $\mathrm{pH} 5-7,7$ dan toleran terhadap unsur fosfat yang rendah.

Nilai $\mathrm{N}$ pada hasil analisis menunjukkan kriteria sedang, yang mana tidak mempengaruhi pertumbuhan legum karena adanya kemampuan untuk mengikat $\mathrm{N}$ dari udara dengan berasosiasi bersama mikroorganisme dalam tanah. Tanaman Indigofera sp. bila berasosiasi dengan bakteri tanah rhizobium mampu memfiksasi N2 dari udara, yang merupakan sumber nitrogen dalam bentuk tidak tersedia untuk tanaman dan mengubahnya menjadi $\mathrm{NO} 3$ atau NH4 yang merupakan bentuk nitrogen tersedia untuk tanaman, sehingga dapat memperkaya kandungan nitrogen di dalam tanah (Ginting et al., 2012). Hasil analisis nilai $P$ menunjukkan kriteria tinggi hingga sangat tinggi, dapat berfungsi dalam proses pembentukan biji pada tanaman (Fanindi, 2009).

Berdasarkan beberapa kriteria sifat kimia tanah hasil analisis yang cenderung rendah, maka diperlukan proses pemupukan untuk digunakan dalam penelitian. Hasil analisis (Lampiran 11), sifat kimia pupuk diperoleh nilai $\mathrm{pH}$ yang baik untuk meningkatkan $\mathrm{pH}$ campuran media 
tumbuh pada saat penelitian. Kandungan C-organik dan rasio $\mathrm{C} / \mathrm{N}$ menunjukkan kematangan top kompos, yaitu terjadinya degradasi bahan organik yang baik, sehingga tersedia unsur hara makro dan mikro untuk meningkatkan kesuburan media tumbuh yang digunakan. Demikian juga pada kriteria unsur Nitrogen, $\mathrm{P}_{2} \mathrm{O}_{5}$ dan $\mathrm{K}_{2} \mathrm{O}$. Kompos ini berperan juga dalam meningkatkan Kapasitas Tukar Kation (KTK) dan memperbaiki struktur tanah (Hardjowigeno, 1989).

Suhu dan kelembaban rumah sungkup pada saat penelitian di bulan Agustus hingga November 2017, berkisar antara $21,2{ }^{0} \mathrm{C}-33,4{ }^{0} \mathrm{C}$, dengan kelembaban sebesar $41 \%$ - 99 $\%$. Rendahnya temperatur disebabkan karena pada saat penelitian, terjadi curah hujan yang signifikan, bergantian dengan musim panas. Sutopo (2004) menyatakan bahwa temperatur merupakan salah satu syarat penting bagi perkecambahan benih. Kebanyakan tanaman tropika membutuhkan temperatur tinggi untuk perkecambahannya.

\section{Penelitian Tahap Pertama}

\section{Lama Berkecambah Benih Indigofera zollingeriana '}

Berdasarkan penelitian yang telah dilakukan, didapatkan nilai ratarata lama berkecambah benih Indigofera zollingeriana (hari), yang disajikan pada Tabel 1.

Tabel 1. Rata-rata Lama Berkecambah Benih Indigofera zollingeriana (hari) Menurut Perlakuan Suhu Rendaman dan Media Tumbuh

\begin{tabular}{ccccc}
\hline $\begin{array}{c}\text { Suhu } \\
\text { Rendaman }\end{array}$ & \multicolumn{3}{c}{ Media Tumbuh } & Rata- \\
\cline { 2 - 4 } & M1 & M2 & M3 & rata \\
\hline S1 & 6,67 & 7,05 & 7,39 & $\mathbf{7 , 0 3}$ \\
S2 & 7,18 & 7,46 & 7,60 & $\mathbf{7 , 4 2}$ \\
\hline Rata-rata & $\mathbf{6 , 9 2}$ & $\mathbf{7 , 2 5}$ & $\mathbf{7 , 5 0}$ & \\
\hline Keterangan: & & & &
\end{tabular}

$\mathrm{S} 1=$ suhu $70^{\circ} \mathrm{C}, \mathrm{S} 2=80^{\circ} \mathrm{C}, \mathrm{M} 1=100 \%$ tanah, $\mathrm{M} 2=75 \%$ tanah $+25 \%$ top kompos, M3 $=50 \%$ tanah $+50 \%$ top kompos.

Pada Tabel 1. terlihat bahwa lama berkecambah benih Indigofera zollingeriana berkisar antara 6,6667 7,6035 hari. Hasil ini mendukung pernyataan Suhendi (1979), bahwa waktu berkecambah yang dibutuhkan setelah benih ditanam adalah $7-15$ hari. Waktu yang pendek sangat berarti karena semakin cepat semai meninggalkan masa sukulen, akan lebih baik.

Hasil Manova (Multivariate Analysis of Variance) menunjukkan bahwa perlakuan suhu awal rendaman, media tumbuh dan interaksinya, tidak berpengaruh signifikan terhadap lama berkecambah benih Indigofera zollingeriana. Hal ini mengindikasikan bahwa lama berkecambah tidak dipengaruhi oleh perlakuan sebelum benih disemaikan. Kartasapoetra (2003), bahwa benih yang kecepatan berkecambahnya tinggi, tanaman yang dihasilkannya akan lebih tahan terhadap keadaan atau lingkungan yang kurang menguntungkan. Hal ini sejalan dengan pernyataan Schmidt (2000), yang mengemukakan bahwa perkecambahan sangat bergantung pada ketersediaan air, temperatur, cahaya, dan kualitas benih yang bebas dari hama dan penyakit.

\section{Daya Kecambah Benih Indigofera zollingeriana}

Menurut Sadjad et al. (1999) daya kecambah menggambarkan viabilitas potensial benih dihitung berdasarkan persentase kecambah normal dibagi jumlah benih yang dikecambahkan. Selanjutnya Sutopo (2004) menyatakan bahwa daya kecambah merupakan jumlah kecambah normal yang dapat dihasilkan oleh benih pada lingkungan optimal. 


\begin{tabular}{|c|c|c|c|c|}
\hline \multirow{2}{*}{$\begin{array}{c}\text { Suhu } \\
\text { Rendaman }\end{array}$} & \multicolumn{3}{|c|}{ Media Tumbuh } & \multirow{2}{*}{$\begin{array}{c}\text { Rata- } \\
\text { rata }\end{array}$} \\
\hline & M1 & M2 & M3 & \\
\hline S1 & 100,00 & 70,67 & 76,00 & 82,22 \\
\hline S2 & 92,00 & 73,33 & 61,33 & 75,56 \\
\hline Rata-rata & $96,00^{a}$ & $72,00^{b}$ & $68,67^{b}$ & \\
\hline
\end{tabular}

zollingeriana, terlihat bahwa daya kecambah terbaik pada perlakuan S1M1 $\left(70^{\circ} \mathrm{C}\right.$ dan $100 \%$ tanah) dan terendah pada perlakuan S2M3 $\left(80^{\circ} \mathrm{C}\right.$ dan $50 \%$ tanah $+50 \%$ top kompos), dengan nilai masing-masing sebesar $100 \%$ dan $61,3 \%$. Tingginya daya kecambah pada kombinasi perlakuan (S1M1), sesuai dengan pernyataan Sutopo (2004) dan Permentan (2013) bahwa syarat benih yang bermutu baik adalah memiliki daya kecambah minimal $80 \%$, daya tumbuh yang baik, tidak terinfeksi cendawan, benih sehat, bernas, mengkilat, dan tidak keriput. Selanjutnya, penyebab rendahnya daya kecambah benih dapat disebabkan karena tipe dormansi benih, yaitu impermeabilitas kulit biji terhadap air, dimana pengabsorbsian air terhalang oleh kulit biji yang keras, terdiri dari lapisan sel-sel serupa palisade berdinding tebal terutama pada permukaan paling luar dan bagian dalamnya mempunyai lapisan lilin dari bahan kutikula. Selain itu, Lodong et al. (2015) menyatakan bahwa daya kecambah dan kecepatan tumbuh yang tinggi secara tidak langsung akan mempengaruhi pertumbuhan bibit selanjutnya, disebabkan karena bibit akan segera mengabsorbsi makanannya sendiri dari lingkungan tumbuhnya melalui organ-organ vegetatif.

Selanjutnya, berdasarkan perhitungan persentase daya kecambah, maka dapat diperoleh nilai rata-rata daya kecambah benih Indigofera zollingeriana (\%), yang disajikan pada Tabel 2.
Tabel 2. Rata-rata Daya Kecambah Benih Indigofera zollingeriana (\%) Menurut Perlakuan Suhu Rendaman dan Media Tumbuh

Keterangan :

1. $\mathrm{S} 1=$ suhu $70^{\circ} \mathrm{C}, \mathrm{S} 2=80^{\circ} \mathrm{C}, \mathrm{M} 1=100 \%$ tanah, $\mathrm{M} 2=75 \%$ tanah $+25 \%$ top kompos, $\mathrm{M} 3=50 \%$ tanah $+50 \%$ top kompos.

2. Superskrip a,b yang berbeda menurut baris menunjukkan berbeda sangat nyata $(\mathrm{P}<0.01)$.

Pada Tabel 2, terlihat bahwa suhu awal rendaman benih Indigofera zollingeriana dan interaksi antara suhu awal rendaman dan media tumbuh tidak berpengaruh signifikan terhadap daya kecambah. Namun, faktor yang berpengaruh signifikan untuk meningkatnya persentase daya kecambah benih adalah media tumbuh, dengan nilai rata-rata tertinggi terlihat pada media tumbuh (100\% tanah), yang diikuti dengan media tumbuh (75\% tanah $+25 \%$ top kompos) dan media tumbuh $(50 \%$ tanah $+50 \%$ top kompos), masing-masing sebesar 96.00\%, 72.00\% dan $68.67 \%$. Hasil Manova (Multivariate Analysis of Variance), terlihat bahwa perlakuan media tumbuh yang berpengaruh signifikan terhadap daya kecambah benih, maka dilanjutkan dengan uji Tukey HSD. Pada uji Tukey HSD, menunjukkan pula bahwa M1 vs M2 dan M1 vs M3 berbeda sangat nyata sedangkan M2 vs M3 berbeda tidak nyata.

Hardjowigeno menyatakan bahwa tanah merupakan salah satu media tumbuh yang baik, jika memiliki tata udara yang baik, kemampuan menahan air yang baik dan ruang untuk perakaran yang cukup. Hal ini mengindikasikan bahwa media tumbuh $100 \%$ tanah adalah yang tepat untuk perkecambahan benih Indigofera zollingeriana, jika dibandingkan dengan media tumbuh M2 (75\% tanah $+25 \%$ top kompos) dan media tumbuh M3 
(50\% tanah $+50 \%$ top kompos). Disamping itu, dengan penambahan $25 \%$ dan $50 \%$ top kompos, akan menurunkan daya kecambah benih Indigofera zollingeriana. Sejalan dengan penelitian yang dilakukan oleh Rofik dan Muniarti (2008) bahwa kombinasi perlakuan media tumbuh tanah dan kompos (1:1) menghasilkan daya kecambah benih aren terendah, yaitu sebesar 10\%. Disamping itu, Murniati dan Suminar (2006) menyatakan bahwa benih yang tidak mengalami enforced dormancy, tidak membutuhkan perlakuan pra perkecambahan.

\section{Penelitian Tahap Kedua

Tinggi Tanaman Indigofera
zollingeriana

Berdasarkan penelitian yang telah dilakukan, maka didapatkan nilai ratarata tinggi tanaman Indigofera zollingeriana $(\mathrm{cm})$ yang disajikan pada Tabel 3.

Tabel 3. Rata-rata Tinggi Tanaman Indigofera zollingeriana $(\mathrm{cm})$ Menurut Pelakuan Suhu Rendaman dan Media Tumbuh

\begin{tabular}{ccccc}
\hline $\begin{array}{c}\text { Suhu } \\
\text { Rendaman }\end{array}$ & \multicolumn{3}{c}{ Media Tumbuh } & Rata- \\
\cline { 2 - 4 } & M1 & $\mathbf{M 2}$ & $\mathbf{M 3}$ & rata \\
\hline S1 & 37,33 & 20,86 & 18,58 & $\mathbf{2 5 , 5 9}$ \\
S2 & 36,90 & 28,57 & 17,70 & $\mathbf{2 7 , 7 2}$ \\
\hline Rata-rata & $\mathbf{3 7 , 1 2}^{\text {a }}$ & $\mathbf{2 4 , 7 1}^{\text {b }}$ & $\mathbf{1 8 , 1 4}^{\text {c }}$ & \\
\hline
\end{tabular}

Keterangan :

1. $\mathrm{S} 1=$ suhu $70^{\circ} \mathrm{C}, \mathrm{S} 2=80^{\circ} \mathrm{C}, \mathrm{M} 1=100 \%$ tanah, $\mathrm{M} 2=75 \%$ tanah $+25 \%$ top kompos, $\mathrm{M} 3=50 \%$ tanah $+50 \%$ top kompos.

2. Superskrip a,b,c yang berbeda menurut baris menunjukkan berbeda sangat nyata $(\mathrm{P}<0.01)$.

Pada Tabel 3, terlihat bahwa nilai rata-rata tertinggi, terdapat pada media tumbuh (100\% tanah), yang diikuti oleh media tumbuh $(75 \%$ tanah $+25 \%$ top kompos) dan media tumbuh (50\% tanah $+50 \%$ top kompos), yaitu masing- masing sebesar $37,1167 \mathrm{~cm} ; 24,7111$ $\mathrm{cm}$ dan 18,1389 cm. Hal ini mengindikasikan bahwa semakin cepat benih Indigofera zollingeriana berkecambah dan memiliki daya kecambah yang tinggi pada media tumbuh (M1), maka akan mempengaruhi variabel pertumbuhan selanjutnya (tinggi tanaman) (Lodong et al. (2015). Pertumbuhan tanaman dapat dicirikan oleh penambahan jumlah sel yang disertai dengan pembesaran sel. Dalam keadaan alamiah, fase pertumbuhan awal ditunjukkan oleh laju pertumbuhan bersifat eksponensial kemudian menurun karena adanya faktor-faktor pembatas (Tohari, 2002).

Hasil Manova, menunjukkan bahwa media tumbuh berpengaruh signifikan terhadap variabel tinggi tanaman, namun suhu awal rendaman dan interaksi antara suhu awal rendaman dan media tumbuh tidak memberikan pengaruh yang signifikan terhadap tinggi tanaman Indigofera zollingeriana. Yang dilanjutkan dengan uji lanjut Tukey HSD, dimana terlihat bahwa media tumbuh M1 vs M2, M1 vs M3 dan M2 vs M3 menunjukkan berbeda sangat nyata terhadap variabel tinggi tanaman. Sofyan dan Islam (2006), menyatakan bahwa untuk mendapatkan tanaman yang berproduksi tinggi, maka fase awal penyemaian merupakan fase yang harus diperhatikan, terutama pada saat akan melakukan seleksi tanaman, yaitu tanaman harus sehat dan tumbuh dengan baik, sehingga semai dapat beradaptasi dan menyerap unsur hara yang maksimal dari media tumbuh yang akan digunakan.

Daniel et al. (1992), kegiatan pemisahan/pemindahan semai dari nampan ke polibag, merupakan salah satu faktor yang sangat penting terutama faktor umur semai saat dipisahkan, mengingat pengaruhnya 


\section{Panjang Daun Tanaman Indigofera zollingeriana}

Berdasarkan penelitian yang telah dilakukan, didapatkan nilai rata-rata panjang daun $(\mathrm{cm})$ tanaman Indigofera zollingeriana yang disajikan pada Tabel 5.

Tabel 5. Rata-rata Panjang Daun (cm) Tanaman Indigofera zollingeriana

\begin{tabular}{ccccc}
\hline Suhu & \multicolumn{3}{c}{ Media Tumbuh } & Rata- \\
\cline { 2 - 4 } Rendaman & M1 & M2 & M3 & rata \\
\hline S1 & 2,11 & 1,82 & 1,73 & $\mathbf{1 , 8 9}$ \\
S2 & 2,15 & 1,99 & 1,72 & $\mathbf{1 , 9 5}$ \\
\hline Rata-rata & $\mathbf{2 , 1 3}^{\text {a }}$ & $\mathbf{1 , 9 0}^{\mathbf{b}}$ & $\mathbf{1 , 7 2}^{\mathbf{c}}$ & \\
\hline Menurut & Perlakuan & Suhu & Rendaman \\
dan Media Tumbuh (cm) &
\end{tabular}

Keterangan :

1. $\mathrm{S} 1=$ suhu $70^{\circ} \mathrm{C}, \mathrm{S} 2=80^{\circ} \mathrm{C}, \mathrm{M} 1=100 \%$ tanah, $\mathrm{M} 2=75 \%$ tanah $+25 \%$ top kompos, $\mathrm{M} 3=50 \%$ tanah $+50 \%$ top kompos.

2. Superskrip a,b,c yang berbeda menurut baris menunjukkan berbeda sangat nyata $(\mathrm{P}<0.01)$.

Pada Tabel 5, terlihat bahwa media tumbuh M1 masih memberikan hasil terbaik jika dibandingkan dengan media tumbuh M2 dan M3, dengan nilai masing-masing sebesar 4,94971 cm, $4,17015 \mathrm{~cm}$ dan 3,44851 cm. Berdasarkan Manova, terlihat pula bahwa media tumbuh memberikan pengaruh signifikan terhadap panjang daun tanaman Indigofera zollingeriana jika dibandingkan dengan suhu awal rendaman dan interaksinya, yang tidak memberikan pengaruh yang signifikan. Untuk itu, dilanjutkan dengan uji lanjut Tukey HSD pada media tumbuh M1 vs M2, M1 vs M3 dan M2 vs M3 menunjukkan berbeda sangat nyata.

Hasil analisis ini sejalan dengan penelitian yang dilakukan oleh Hassen et al., (2007) bahwa tanaman Indigofera pada umur 7 bulan, memiliki panjang daun sebesar $6,93 \mathrm{~cm}$. Hal ini mengindikasikan bahwa dengan umur panen yang lebih awal ( 3 bulan), maka panjang daun yang dihasilkan akan semakin pendek.

\section{Lebar Daun Tanaman Indigofera zollingeriana}

Berdasarkan penelitian yang telah dilakukan, diperoleh nilai rata-rata lebar daun $(\mathrm{cm})$ tanaman Indigofera zollingeriana, yang disajikan pada Tabel 6.

Tabel 6. Rata-rata Lebar Daun (cm) Tanaman Indigofera zollingeriana

\begin{tabular}{ccccc}
\hline \multirow{2}{*}{$\begin{array}{c}\text { Suhu } \\
\text { Rendaman }\end{array}$} & \multicolumn{3}{c}{ Media Tumbuh } & Rata- \\
\cline { 2 - 4 } & M1 & M2 & M3 & rata \\
\hline S1 & 4,99 & 3,87 & 3,56 & $\mathbf{4 , 1 4}$ \\
S2 & 4,91 & 4,47 & 3,34 & $\mathbf{4 , 2 4}$ \\
\hline Rata-rata & $\mathbf{4 , 9 5}^{\mathbf{a}}$ & $\mathbf{4 , 1 7}^{\mathbf{b}}$ & $\mathbf{3 , 4 5}^{\mathbf{c}}$ & \\
\hline
\end{tabular}

Berdasarkan Perlakuan Suhu Rendaman dan Media Tumbuh

Keterangan :

1. $\mathrm{S} 1=$ suhu $70^{\circ} \mathrm{C}, \mathrm{S} 2=80^{\circ} \mathrm{C}, \mathrm{M} 1=100 \%$ tanah, $\mathrm{M} 2=75 \%$ tanah $+25 \%$ top kompos, $\mathrm{M} 3=50 \%$ tanah $+50 \%$ top kompos.

2. Superskrip a,b,c yang berbeda menurut baris menunjukkan berbeda sangat nyata $(\mathrm{P}<0.01)$.

Sama halnya dengan beberapa variabel pengamatan lainnya, pada variabel lebar daun, media M1 $(2,13061$ $\mathrm{cm})$ masih memiliki nilai tertinggi, yang diikuti dengan $\mathrm{M} 2(1,90176 \mathrm{~cm})$ dan M3 (1,72345 cm). Hasil Manova, terlihat bahwa media tumbuh memberikan pengaruh signifikan, sedangkan suhu awal rendaman dan interaksi antara suhu awal rendaman dan media tumbuh, tidak memberikan pengaruh signifikan terhadap lebar daun tanaman Indigofera zollingeriana. Serta dilanjutkan dengan uji lanjut Tukey HSD, yang diperoleh M1 vs M2 dan M1 vs M3 menunjukkan berbeda sangat nyata, sedangkan M2 vs M3 menunjukkan berbeda nyata.

Tingginya variabel lebar daun pada media tumbuh M1, menunjukkan bahwa pertumbuhan lebar daun pada tanaman Indigofera zollingeraiana, berfungsi 
sebagai organ utama fotosintesis pada tumbuhan, dimana daun yang diproduksi oleh tanaman budidaya memiliki permukaan luar daun yang luas dan datar, yang memungkinkan menangkap cahaya semaksimal mungkin per satuan volume dan meminimalkan jarak yang harus ditempuh oleh $\mathrm{CO}_{2}$ dari permukaan daun ke kloroplas, dengan jumlah stomata yang banyak per satuan luas (Gardner, et al., 1991).

\section{Rasio Daun dan Batang Tanaman Indigofera zollingeriana}

Berdasarkan penelitian yang telah dilakuakn, didapatkan nilai rata-rata rasio daun dan batang tanaman Indigofera zollingeriana, yang disajikan pada Tabel 7.

Tabel 7. Rata-rata Rasio Daun dan Batang Tanaman Indigofera zollingeriana Berdasarkan Perlakuan Suhu Rendaman dan Media Tumbuh Keterangan :

1. $\mathrm{S} 1=$ suhu $70^{\circ} \mathrm{C}, \mathrm{S} 2=80^{\circ} \mathrm{C}, \mathrm{M} 1=100 \%$ tanah, $\mathrm{M} 2=75 \%$ tanah $+25 \%$ top kompos, $\mathrm{M} 3=50 \%$ tanah $+50 \%$ top kompos.

2. Superskrip a,b yang berbeda menurut baris menunjukkan berbeda sangat nyata $(\mathrm{P}<0.01)$.

Pada Tabel 7 terlihat bahwa rasio daun dan batang tertinggi pada media tumbuh M3 $(3,6275)$, yang diikuti oleh media tumbuh M2 $(3,0305)$ dan M1 $(2,2685)$. Tingginya rasio daun dan batang pada media tumbuh M3, disebabkan karena proses fotosintesis pada daun akan menghasilkan energi yang dapat digunakan untuk pertumbuhan dan perkembangan daun. Banyaknya daun akan mempengaruhi jumlah asimilat yang dihasilkan pada akhirnya berpengaruh pula pada pembentukkan daun dan organ tanaman yang lain (Dwidjoseputro, 1994). Selain itu, nilai rata-rata tersebut sesuai dengan pernyataan Sirait et al., (2007) bahwa rasio daun dan batang berada pada kisaran 1,9 - 4,2 untuk leguminosa dan kisaran 1,8 - 6,5 untuk gramminae, yang mengindikasikan bahwa rasio daun dan batang yang dihasilkan pada M3 ini cukup baik, karena mendekati nilai 4,2 .

Hasil Manova, terlihat bahwa media tumbuh memberikan pengaruh yang signifikan terhadap produksi rasio daun dan batang pada tanaman Indigofera zollingeriana. Sedangkan perlakuan suhu awal rendaman dan interaksi antara suhu awal rendaman dan media tumbuh tidak memberikan pengaruh yang signifikan terhadap variabel rasio daun dan batang tanaman. Untuk itu, dilanjutkan dengan uji lanjut Tukey HSD, dimana media tumbuh M1 vs M2, M1 vs M3 dan M2 vs M3 sangat berbeda nyata untuk variabel ini. Waters dan Givens, (1992) dalam Tarigan et al. (2013) menyatakan bahwa rasio daun dan batang dapat menggambarkan usia dari tanaman yang

\begin{tabular}{lcccr}
\hline $\begin{array}{c}\text { Suhu } \\
\text { Rendaman }\end{array}$ & \multicolumn{3}{c}{ Media Tumbuh } & Rata- \\
\cline { 2 - 4 } & M1 & M2 & M3 & rata \\
\hline S1 & 2,25 & 3,08 & 3,41 & $\mathbf{2 , 9 2}$ \\
S2 & 2,28 & 2,98 & 3,84 & $\mathbf{3 , 0 3}$ \\
\hline Rata-rata & $\mathbf{2 , 2 7}^{\mathbf{a}}$ & $\mathbf{3 , 0 3}$ & $\mathbf{3 , 6 3}$ \\
\hline diamati, yaitu & \multicolumn{2}{c}{ dengan } & semakin \\
menurunnya kandungan nutrisi, akan \\
terlihat pada semakin bertambahnya \\
umur tanaman. Selanjutnya dikatakan \\
pula bahwa helai daun memiliki \\
kandungan protein yang lebih tinggi \\
dibandingkan dengan bagian batang \\
tanaman yang lainnya, dimana \\
kandungan protein pada bagian batang \\
cenderung lebih rendah bila \\
dibandingkan dengan protein kasar \\
fraksidaun.
\end{tabular}

\section{Panjang Akar Tanaman Indigofera zollingeriana}

Nilai rata-rata hasil Manova (Multivariate Analysis of Variance) pada variabel panjang akar (cm) 
tanaman Indigofera zollingeriana, yang disajikan pada Tabel 8 .

Tabel 8. Rata-rata Panjang Akar (cm) Tanaman Indigofera zollingeriana Menurut Perlakuan Suhu Rendaman dan Media Tumbuh

Keterangan :

$\mathrm{S} 1=$ suhu $70^{\circ} \mathrm{C}, \mathrm{S} 2=80^{\circ} \mathrm{C}, \mathrm{M} 1=100 \%$ tanah, $\mathrm{M} 2=75 \%$ tanah $+25 \%$ top kompos, M3 $=50 \%$ tanah $+50 \%$ top kompos.

Berdasarkan Tabel 8, terlihat bahwa suhu awal rendaman, media tumbuh dan interaksi antara suhu dan media tumbuh tidak memberikan pengaruh yang signifikan terhadap variabel panjang akar. Oleh karena kombinasi perlakuan ini tidak memberikan pengaruh yang signifikan, maka tidak dilanjutkan dengan uji lanjut

\begin{tabular}{ccccc}
\hline \multirow{2}{*}{$\begin{array}{c}\text { Suhu } \\
\text { Rendaman }\end{array}$} & \multicolumn{3}{c}{ Media Tumbuh } & Rata- \\
\cline { 2 - 4 } & M1 & M2 & M3 & rata \\
\hline S1 & 7,11 & 23,56 & 16,78 & $\mathbf{1 5 , 8 1}$ \\
S2 & 6,33 & 25,78 & 22,56 & $\mathbf{1 8 , 2 2}$ \\
\hline Rata-rata & $\mathbf{6 , 7 2}^{\text {b }}$ & $\mathbf{2 4 , 6 7}^{\text {b }}$ & $\mathbf{1 9 , 6 7}^{\text {a }}$ & \\
\hline
\end{tabular}

Tukey HSD. Hal ini disebabkan karena untuk variabel ini, tanaman Indigofera zollingeriana ditanam pada polibag yang menyebabkan akar hanya bisa tumbuh sebatas ruang yang ada di dalam polibag, sehingga tidak terdapat pengaruh dari suhu, media dan interaksinya, akar tetap tidak bisa tumbuh maksimal. Hartmann dan Kester (1983) menyatakan bahwa terdapat senyawa khusus selain auksin yang berperan dalam perakaran yang disebut rooting cofactor. Senyawasenyawa fenol seperti cafeic acid, cathecol dan chorogenic acid terbukti berinteraksi dengan auksin membantu proses pembentukan akar. Reaksi senyawa-senyawa tersebut dengan auksin beserta bantuan enzim akan membentuk suatu kompleks senyawa yang disebut rhizocaline. Tunas yang baru muncul dan daun-daun muda adalah bagian tanaman yang menghasilkan auksin. Dalam perkembangan selanjutnya auksin akan merangsang pembentukan akar (Leopold dan Kriedemann, 1975). Tampaknya dengan banyaknya akar yang terbentuk akan dengan cepat pula melakukan kegiatan menyerap makanan

\begin{tabular}{ccccc}
\hline \multirow{2}{*}{$\begin{array}{c}\text { Suhu } \\
\text { Rendaman }\end{array}$} & \multicolumn{3}{c}{ Media Tumbuh } & Rata- \\
\cline { 2 - 4 } & M1 & M2 & M3 & rata \\
\hline S1 & 31,36 & 27,31 & 28,03 & $\mathbf{2 8 , 9 0}$ \\
S2 & 28,20 & 32,47 & 32,07 & $\mathbf{3 0 , 9 1}$ \\
\hline Rata-rata & $\mathbf{2 9 , 7 8}$ & $\mathbf{2 9 , 8 9}$ & $\mathbf{3 0 , 0 5}$ & \\
\hline
\end{tabular}

dari dalam tanah.

\section{Jumlah Bintil Akar Tanaman Indigofera zollingeriana}

Berdasarkan penelitian yang telah dilakukan, didapatkan nilai rata-rata jumlah bintil akar tanaman Indigofera zollingeriana, yang disajikan pada Tabel 9.

Tabel 9. Rata-rata Jumlah Bintil Akar Tanaman Indigofera zollingeriana Menurut Perlakuan Suhu Rendaman dan Media Tumbuh

Keterangan :

1. $\mathrm{S} 1=$ suhu $70^{\circ} \mathrm{C}, \mathrm{S} 2=80^{\circ} \mathrm{C}, \mathrm{M} 1=100 \%$ tanah, $\mathrm{M} 2=75 \%$ tanah $+25 \%$ top kompos, $\mathrm{M} 3=50 \%$ tanah $+50 \%$ top kompos.

2. Superskrip a,b,c yang berbeda menurut baris menunjukkan berbeda sangat nyata $(\mathrm{P}<0.01)$.

Pada Tabel 9 terlihat bahwa jumlah bintil akar tertinggi pada media tumbuh M2 (24,67), yang diikuti oleh media tumbuh M3 $(19,67)$ dan M1 $(6,72)$. Hal ini disebabkan karena, pada saat pengamatan dan pengkuran pada tahap akhir penelitian, peneliti dapat melihat bahwa, tanaman Indigofera zollingeriana yang tumbuh pada media M2 lebih banyak menghasilkan bintilbintik akar, sedangkan pada media tumbuh M1 terlihat bahwa bintil akar yang dihasilkan sedikit bahkan ada tanaman yang belum terdapat bintil akar.

Hasil Manova, terlihat bahwa media tumbuh memberikan pengaruh yang signifikan, jika dibandingkan 
dengan suhu awal rendaman serta interaksi antara suhu awal rendaman dan media tumbuh yang tidak memberikan pengaruh yang signifikan terhadap variabel jumlah bintil akar tanaman Indigofera zollingeriana. Untuk itu dilakukan uji lanjut Tukey HSD pada variabel terikat (media tumbuh), sehingga diperoleh M1 vs M2 dan M1 vs M3 berbeda sangat nyata, serta M2 vs M3 berbeda nyata pada variabel ini. Indriyanto (2005) menyatakan bahwa nodul akar atau bintil akar adalah bentuk simbiosis mutualisme antara bakteri Rhizobium spp., dengan akar tumbuhan. Selanjutnya, simbiosis tersebut terjadi pada tumbuhan anggota famili Fabaceae (Leguminosae), akan tetapi ada juga beberapa spesies pohon yang memiliki nodul akar, yaitu Podocarpus spp., Casuarina spp., Pinus spp., Ginkgo spp., Araucaria spp., Alnus spp. dan Myrica spp. Rhizobium adalah bakteri yang memiliki kemampuan menambat nitrogen dari udara dalam proses yang disebut fiksasi biologis. Dengan demikian, peranan bintil akar sangat penting dalam meningkatkan jumlah unsur nitrogen tanah maupun nitrogen yang diperlukan oleh tumbuhan inangnya.

\section{KESIMPULAN}

Berdasarkan hasil penelitian yang telah diperoleh, disimpulkan bahwa:

1. Lama dan daya kecambah terbaik dari benih Indigofera zollingeriana adalah dengan menggunakan suhu awal rendaman $70^{\circ} \mathrm{C}$ dan media tumbuh $100 \%$ tanah.

2. Pada variabel tinggi tanaman, jumlah daun, panjang daun, dan lebar daun terbaik dari tanaman Indigofera zollingeriana adalah dengan menggunakan suhu awal rendaman $80^{\circ} \mathrm{C}$ dan media tumbuh $100 \%$ tanah.

3. Suhu awal rendaman $80^{\circ} \mathrm{C}$ dan media tumbuh $50 \%$ tanah $+50 \%$ top kompos memberikan hasil terbaik terhadap rasio daun dan batang serta panjang akar tanaman Indigofera zollingeriana.

4. Suhu awal rendaman $80^{\circ} \mathrm{C}$ dan media tumbuh $75 \%$ tanah $+25 \%$ top kompos memberikan hasil terbaik terhadap jumlah bintil akar tanaman Indigofera zollingeriana.

5. Penggunaan top kompos sebaiknya digunakan setelah tanaman berumur tiga bulan, agar dapat mempercepat pertumbuhan dan produksi tanaman Indigofera zollingeriana.

\section{DAFTAR PUSTAKA}

Abdullah L., 2014. Prospektif Agronomi dan Ekofisiologi Indigofera zollingeriana Sebagai Tanaman Penghasil Hijauan Pakan Berkualitas Tinggi. Jurnal Pastura 3(2):79-83.

Abdullah L., 2014. Mewujudkan Konsentrasi Hijau (Green Concentrate) dalam Industri Baru Pakan Untuk Mendorong Kemandirian Pakan dan Daya Saing Peternakan Nasional. Orasi Ilmiah Guru Besar Fakultas Peternakan IPB, Bogor.

Abdullah L dan Kumalasari N.R., 2016. Panduan Teknis Budidaya dan Pemanenan Indigofera zollingeriana. PT. Penerbit IPB Press, Bogor.

Ani N., 2006. Pengaruh Perendaman Benih dalam Air Panas Terhadap Daya Kecambah dan Pertumbuhan Bibit Lamtoro (Leucaena leucocephala). Jurnal Penelitian 
Bidang Ilmu Pertanian Vol. 4 No. 1, April 2006:24-28.

Bajang M.E, A. Rumambi, W.B. Kaunang dan D. Rustandi, 2015. Pengaruh Media Tumbuh dan Lama Perendaman Terhadap Perkecambahan Sorgum Varietas Numbu. Jurnal Zootek ("Zootek Journal) Vol. 35 No. 2:302-311 (Juli 2015).

Daniel, T.W., Helms J.A., Baker F.S. 1992. Prinsip-prinsip Silvikultur. Marsono D., penerjemah; Soesono O.H., Ed. Yogyakarta. Gajah Mada University Press. Terjemahan dari : Principles of Silviculture.

Dwidjoseputro. 1994. Pengetahuan Fisiologi Tumbuhan. Gramedia. Jakarta. p232.

Fanindi A. 2009. Pengaruh Intensitas Cahaya Terhadap Produksi dan Kualitas Hijauan Serta Benih Legum Tanaman Pakan. Tesis, sekolah Pascasarjana, Institut Pertanian Bogor.

Gandhi D., S. Albert and N. Pandya, 2011. Morphological and Micromorphological

Characterization of Some Legume Seeds from Gujarat, India. Environmental and Experimental Biology 9:105-113.

Gardner F. P., R. B. Pearce dan R. L. Mitchell (1991). Fisiologi Tanaman Budidaya. Penerbit Universitas Indonesia (UI-Press).

Ginting S.P., B.R. Prawiradiputra, dan N.D. Purwantari, 2012. Indigofera Sebagai Pakan Ternak. Pusat Penelitian dan Pengembangan
Peternakan: IAARD Press, Jakarta.

Hassen A, Rethman N.F.G, Van Niekerk, Tjelele T.J., 2007. Influence of season/year and species on chemical composition and in vitro digestibility of five Indigofera accessions. Anim Feed Sci Technol. 136:312-322.

Hardjowigeno S., 1989. Pengantar Ilmu Tanah. Medyatama Sarana Perkasa, Jakarta.

Hardjowigeno S., 2010. Ilmu Tanah. Penerbit Akademika Pressindo, Jakarta.

Hartmann, H.T. dan D.E. Kester. 1983. Plant Propagation ; Principles and Practices. Fourth Edition. Prentice Hall, Inc. Englewood Cliffs. New Jersey.

Herdiawan I. dan R. Krisnan, 2014. Produktivitas dan Pemanfaatan Tanaman Leguminosa Pohon Indigofera zollingeriana Pada Lahan Kering.

Indriyanto, 2005. Ekologi Hutan. PT. Bumi Aksara. Jakarta.

Kartasapoetra, A.G., 2003. Teknologi Benih Pengolahan Benih Dan Tuntunan Praktikum . PT. Asdi Mahasatya, Jakarta.

Leopold, A.C. dan P.E. Kriedemann. 1975. Plant Growth and Development. McGrow Hill Book Company. New York.

Lodong, O., Y. Tambing dan Adrianton. 2015. Peranan kemasan dan media simpan terhadap ketahanan viabilitas dan vigor benih nangka 
(Artocarpus heterophyllus Lamk) kultivar tulo-5 selama penyimpanan. e-J. Agrotekbis. 3(3): 303-3015.

Murniati. E. dan M. Suminar, 2006. Pengaruh Jenis Media Perkecambahan dan Perlakuan Pra Perkecambahan Terhadap Viabilitas Benih Mengkudu (Morinda citrifolia L.) dan Hubungannya Dengan Sifat Dormansi Benih. Bul. Agronomi. 34 (2):119-123.

Peraturan Menteri Pertanian Nomor 90/Permentan/OT.140/9/2013.

Standar Operasional Prosedur Penetapan Kebun Sumber Benih, Sertifikasi Benih, dan Evaluasi Kebun Sumber Benih Tanaman Kakao (Theobroma cacao L.).

Rofik A. dan E. Murniati E., (2008). Pengaruh Perlakuan Deoperkulasi Benih dan Media Perkecambahan Untuk Meningkatkan Viabilitas Benih Aren (Arenga pinnata (Wurmb.) Merr.). Bulletin Agronomi. (36) (1) $33-40$.

Sadjad, S., Muniarti, E., Ilyas, S. 1999. Parameter Pengujian Vigor Benih dari Komperatif ke Simulatif. Grasindo Gramedia Widiasarana Indonesia, Jakarta.

Schmidt, L. 2000. Pedoman Penanganan Benih Tanaman Hutan Tropis dan Subtropis. Terjemahan. Kerjasama Direktorat Jenderal Rehabilitasi Lahan dan Perhutanan Sosial denganIndonesia Forest Seed Project. PT. Gramedia Jakarta.

Shehu, Y., W. S. Alhassan, U. R. Pal, dan C. J. C. Phillips. 2001. Yield and Chemical Composition Response of Lab Purpureus to Nitrogen, Phosphorus and Potassium Fertilizers. Trop Grassl. 35:180-185.
Steel R.G.D and J.H. Torrie., 1995. Prinsip dan Prosedur Statistika: Suatu Pendekatan Biometrika. Jakarta (Indones): PT. Gramedia.

Suhendi, H. 1979. Hasil Pendahuluan Mengenai Perkecambahan dan Pertumbuhan Gmelina arborea L. di Persemaian. Lembaga Penelitian Hutan. Bogor.

Sirait J., A. Tarigan, K. Simanihuruk dan Junjungan, 2007. Produksi dan Nilai Nutrisi Enam Spesies Hijauan Pada Tiga Taraf Naungan Di Dataran Tinggi-Beriklim kering. Seminar Nasional Teknologi Peternakan dan Veteriner.

Sitompul, S.M. dan B. Guritno. 1995. Analisis Pertumbuhan Tanaman. Gadjah Mada University Press. Yogyakarta. p412.

Sumanto dan Sriwahyuni, 1993. Pengembangan Perlakuan Benih Terhadap Perkecambahan. Pusat Penelitian dan Pengembangan Tanaman Industri.

Suprayitno, 1981. Lamtoro Gung dan Manfaatnya. Bharata Karya Aksara, Jakarta.

Sutopo L. 2004. Teknologi Benih. Edisi Revisi. PT. Raja Grafindo Persada, Jakarta.

Tarigan A., (2009). Produktivitas dan Pemanfaatan Indigofera $s p$. Sebagai Pakan Ternak Kambing Pada Interval dan Intensitas Pemotongan Berbeda. Tesis. Sekolah Pascasarjana, Institute Pertanian Bogor, Bogor.

Tarigan A., J. Sirait dan SP. Ginting, 2013. Produksi dan Komposisi Nutrisi Indigofera sp. pada Intensitas Pemotongan dan Jarak Tanam yang Berbeda di Dataran Tinggi dengan Curah Hujan Sedang. Seminar Nasional Teknologi Peternakan dan Veteriner. 
Tohari, 2002. Pertumbuhan dan Perkembangan Tanaman. Program Pascasarjana UGM. Yogyakarta.

Topps J.H., 1992. Potential Composition and Use of Legume Shrubs and Trees as Fodders for Livestock in the Tropics. Journal Agric. Sci. $118: 1-8$. 